\title{
Detection of Tick-Borne Pathogens in Red Deer (Cerous elaphus), United Kingdom
}

\author{
Nicholas Johnson *, Megan Golding (1) and Laurence Paul Phipps \\ Arbovirus Research Team, Virology Department, Animal and Plant Health Agency (Weybridge), Woodham Lane, \\ Addlestone KT15 3NB, UK; Megan.Golding@apha.gov.uk (M.G.); Paul.Phipps@apha.gov.uk (L.P.P.) \\ * Correspondence: Nick.Johnson@apha.gov.uk
}

Citation: Johnson, N.; Golding, M.; Phipps, L.P. Detection of Tick-Borne Pathogens in Red Deer (Cervus elaphus), United Kingdom. Pathogens 2021, 10, 640. https://doi.org/ 10.3390 / pathogens 10060640

Academic Editors: Vett Lloyd and Natasha Rudenko

Received: 21 April 2021

Accepted: 19 May 2021

Published: 23 May 2021

Publisher's Note: MDPI stays neutral with regard to jurisdictional claims in published maps and institutional affiliations.

Copyright: (c) 2021 by the authors. Licensee MDPI, Basel, Switzerland. This article is an open access article distributed under the terms and conditions of the Creative Commons Attribution (CC BY) license (https:// creativecommons.org/licenses/by/ $4.0 /)$.

\begin{abstract}
Deer represent a major vertebrate host for all feeding stages of the hard tick Ixodes ricinus in the United Kingdom (UK), and could play a role in the persistence of tick-borne pathogens. However, there have been few studies reporting the presence of Babesia spp. and Anaplasma phagocytophilum in deer in the UK, and those that detected Babesia were unable to confirm the species. To address this, we have investigated blood samples from red deer (Cervus elaphus) for the presence of tick-borne pathogens. Total DNA was extracted from haemolysed blood that was removed from clotted blood sampled from culled, captive red deer. Babesia spp. were detected with a pan-piroplasm PCR that amplifies a fragment of the 18S rRNA gene. Species were identified based on identity with published sequences. Anaplasma phagocytophilum was detected with a probe-based PCR targeting the $m s p 2$ gene. In addition, residual serum samples from a subset of animals were tested for the presence of anti-flavivirus antibodies. Of 105 red deer samples tested from three locations in the United Kingdom, 5 were positive for piroplasm and 5 were positive for A. phagocytophilum. Co-infection with both pathogens was detected in two samples from one location. No evidence for antibodies against West Nile virus were detected. However, $12 \%$ of sera tested were positive for tick-borne encephalitis virus antibodies.
\end{abstract}

Keywords: Babesia; Anaplasma phagocytophilum; red deer; 18S rRNA gene; flavivirus

\section{Introduction}

Deer play an active role in the epidemiology of a range of livestock and human pathogens [1,2]. In the British Isles there are six species of deer. Two species are considered native, red deer (Cervus elaphus) and roe deer (Capreolus capreolus). A third species, fallow deer (Dama dama), was introduced during the medieval period. Three other species have established in the United Kingdom since their original introductions in the 19th century, Japanese sika (Cervus nippon), Reeve's muntjac (Muntiacus reevesi) and Chinese water deer (Hydropotes inermis). Surveys in recent decades have suggested that they are all increasing in abundance and increasing in range, particularly the recently introduced species [3]. All are targets for tick predation as they generally occupy habitats where Ixodes ricinus ticks are prevalent, such as deciduous woodland and moorland. Based on these factors, deer have the potential to act as a key vertebrate reservoir for blood-borne pathogens.

The order Piroplasmida is dominated by two genera of tick-borne protozoal parasites, Babesia and Theileria [4]. In the United Kingdom, clinical disease caused by Theileria spp. is rarely encountered [5], but infection with Babesia divergens causes the main tick-borne disease of cattle, bovine Babesiosis, which is often termed redwater fever [6] and is found throughout the British Isles [7]. Babesia divergens is transmitted by I. ricinus and has been detected in cattle repeatedly over the past 100 years [8,9]. Other Babesias detected in ruminants include B. major, also in cattle [10], and B. motasi in sheep [11]. However, outbreaks of disease are sporadic and the maintenance of Babesia spp. within the tick population is likely to depend on wildlife species acting as the vertebrate host. Anaplasma 
phagocytophilum is a tick-borne Gram-negative bacterium in the family Anaplasmataceae, which has a worldwide distribution. It primarily infects neutrophils and, to a lesser extent, eosinophils, during the initial phase of the disease in vertebrate hosts, later infecting host lymphocytes. Anaplasma phagocytophilum is the etiological agent of human granulocytic anaplasmosis (HGA) in North America [12], but cases are rare in Europe [13]. By contrast, A. phagocytophilum infection is common in European livestock, causing tick-borne fever in cattle and sheep, as well as equine granulocytic anaplasmosis. Anaplasma phagocytophilum has been detected in British roe deer [14] and numerous studies from mainland Europe have detected the infection in roe deer $[15,16]$, red deer $[17,18]$ and fallow deer [19]. Co-infection with Babesia spp. is often reported.

The first evidence that UK deer could be involved in the epidemiology of bovine babesiosis was reported in the 1970s. Preliminary studies had reported that sera from Scottish red deer were seropositive for $B$. divergens [20]. This was followed by the isolation of Babesia species from the blood of wild deer [21]. The morphology of this Babesia was indistinguishable from B. divergens and B. capreoli, originally described by Enigk and Freidhoff in 1962 [22]. In addition to these two species, others have been identified in mainland Europe. Sequence from spleen samples from both roe and red deer in Slovenia [23] identified two species, one with high sequence identity to $B$. divergens and a second sharing identity with a species designated EU1 [24]. This species was also detected in French roe deer [25] and is now named B. venatorum. This species, like B. divergens, but not other Babesia species, is zoonotic and has been detected in UK ticks [26]. It has recently been reported in blood samples taken from healthy sheep in Scotland [27]. A further species has been detected in European deer and appears to be closely related to a Babesia found in white-tailed deer (Odocoilus virginianus) in the Great Dismal Swamp of Virginia, United States of America. The US Babesia was tentatively named B. odocoilei by Emerson and Wright [28]. More recently this species has been associated with deer from around the world [29-31] and is often referred to as B. odocoilei-like. A number of studies have surveyed for piroplasms in wild and farmed cervids within the Iberian Peninsula. In contrast to North European countries, surveys of deer have detected Theileria spp., with the occasional detection of B. divergens, in roe deer [32]. The only Babesia species detected in farmed red deer from central and southern Spain was B. pecorum [33], whilst a survey of wildlife in Portugal that included red and fallow deer, and wild boar (Sus scrofa), only detected Theileria spp. [34]. This may reflect the different tick assemblages found throughout the region, with drier areas dominated by Hyalomma species rather than I. ricinus. This suggests that there are at least four species of Babesia commonly encountered when surveying deer in northern Europe. A further development has been the detection of seropositivity for tick-borne encephalitis virus (TBEV) in deer sera and the isolation of TBEV from ticks in areas of high seroprevalence in Great Britain [35].

The persistence of livestock disease caused by $B$. divergens and A. phagocytophilum within the British Isles $[9,26,36]$, increasing knowledge of Babesia diversity in wild ungulates in mainland Europe [37], and the discovery of piroplasmids that rarely cause livestock disease $[5,27]$ has prompted us to investigate the presence of Babesia spp. and A. phagocytophilum in red deer from three locations within Scotland and England. We have also tested serum samples for the presence of antibodies against the flaviviruses West Nile virus $(\mathrm{WNV})$ and TBEV.

\section{Results}

Blood samples were obtained from culled red deer from three locations, as outlined in Table 1. Anaplasma phagocytophilum was detected from three samples from Norfolk, one sample each from Dumfries and Galloway, and Lancashire. Piroplasm DNA was detected in two samples each from Norfolk and Dumfries and Galloway, and in one sample from Lancashire. Dual infection with piroplasm and A. phagocytophilum was detected in two samples (N406 and N408) from Norfolk. The level of detection within the pan-piroplasm assay as judged by the PCR threshold value $(\mathrm{Ct})$ was relatively high in the deer samples 
(>35) compared to equivalent results for cattle with Babesiosis, where the threshold values are usually in the range of 20 to 25.

Table 1. Sample details of 105 red deer (Cervus elaphus) from three locations in the United Kingdom. Results for A. phagocytophilum and pan-piroplasm PCR on DNA extracted from each sample are given.

\begin{tabular}{|c|c|c|c|c|}
\hline Location & Year/Samples & Total & $\begin{array}{c}\text { Anaplasma } \\
\text { phagocytophilum PCR } \\
(\%) \text { [Code Numbers] }\end{array}$ & $\begin{array}{l}\text { Pan-Piroplasm spp. PCR } \\
\text { (\%) [Code Numbers] }\end{array}$ \\
\hline Norfolk (N) & $\begin{array}{c}2020 \\
0 \sigma^{2}, 11 \text { ㅇ }\end{array}$ & 11 & $\begin{array}{c}3 / 11(27.3 \%) \\
{[\mathrm{N} 405, \mathrm{~N} 406, \mathrm{~N} 408]}\end{array}$ & $\begin{array}{l}2 / 11(18.2 \%) \\
{[N 406, N 408]}\end{array}$ \\
\hline $\begin{array}{l}\text { Dumfries and } \\
\text { Galloway (DG) }\end{array}$ & $\begin{array}{c}2020 \\
50 \sigma^{\top}, 180\end{array}$ & 68 & $\begin{array}{c}1 / 68(1.5 \%) \\
\text { [DG422] }\end{array}$ & $\begin{array}{c}2 / 68(2.9 \%) \\
{[D G 368, \text { DG393] }}\end{array}$ \\
\hline Lancashire (L) & $\begin{array}{c}2020 \\
13 \sigma^{\top}, 139\end{array}$ & 26 & $\begin{array}{c}1 / 26(3.8 \%) \\
{[\mathrm{L} 811]}\end{array}$ & $\begin{array}{c}1 / 26(3.8 \%) \\
{[\mathrm{L} 801]}\end{array}$ \\
\hline Totals & & 105 & $5 / 105(4.8 \%)$ & $5 / 105(4.8 \%)$ \\
\hline
\end{tabular}

Sequencing of the pan-piroplasm amplicon generated a 363-base pair (bp) sequence from four samples (N406, DG368, DG393, L801). Sample N408 produced a partial sequence that was not subsequently analysed. Alignment of these sequences with publicly available Babesia 18S rDNA sequences demonstrated that they shared $>99.7 \%$ sequence identity with those derived from red deer sampled in the Czech Republic [37]. Alignment of a $56 \mathrm{bp}$ fragment including the hypervariable region amplified by primers Piro- $\mathrm{A}$ and Piro-B of deer-associated 18S rDNA sequences (B. divergens, B. capreoli, B. venatorum and deerclade Babesia) indicated that deer-clades' sequences, including the sequences generated in this study, contain a single base deletion within this region (Figure 1A). The other species generate a $364 \mathrm{bp}$ sequence using these primers. A neighbour-joining analysis (Figure 1B) of deer-associated Babesia spp. showed the clustering of the UK sequence with the Czech "deer-clade" sequences with $>99.7 \%$ sequence identity (GenBank Accession number MG344776) and diverges from a B. odocoilei sequence (AY046577) from North America with $100 \%$ bootstrap support. This cluster is separate from the major clade containing B. venatorum, B. divergens, and B. capreoli.

Following the recent detection of TBEV in ticks sampled in the UK associated with high levels of seropositivity in deer for this virus, the samples were also screened for flavivirus antibodies. No WNV antibodies were detected in any of the deer samples tested (Table 2). However, $12 \%$ of samples tested positive for TBEV by ELISA, the majority from deer sampled in Dumfries and Galloway (Table 2).

Table 2. Serosurvey for flaviviruses in deer samples from the United Kingdom.

\begin{tabular}{ccc}
\hline Location & $\begin{array}{c}\text { West Nile Virus }^{1} \\
\text { (ID Screen }{ }^{\circledR} \text { West Nile } \\
\text { Competition Multi-Species) (\%) }\end{array}$ & $\begin{array}{c}\text { Tick-Borne Encephalitis Virus }^{2} \\
\text { (Immunozym FSME IgG All } \\
\text { Species) (\%) }\end{array}$ \\
\hline Norfolk & $0 / 9(0)$ & $0 / 9(0)$ \\
Dumfries and Galloway & $0 / 14(0)$ & $4 / 15(26.7)$ \\
Lancashire & $0 / 16(0)$ & $1 / 17(5.9)$ \\
\hline Total & $0 / 39(0)$ & $5 / 41(12.1)$ \\
\hline
\end{tabular}

${ }^{1}$ positive values: $\mathrm{S} / \mathrm{N} \%<40 \% ;{ }^{2}$ positive values: $>126 \mathrm{VIEU} / \mathrm{mL}$. ${ }^{\circledR}$ registered trademark. 


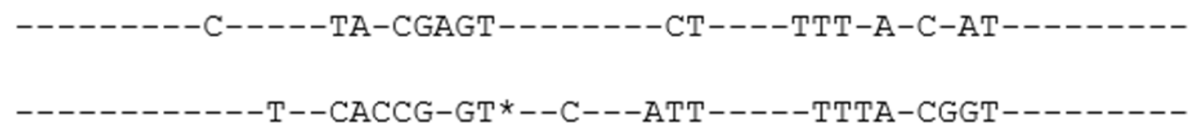

B

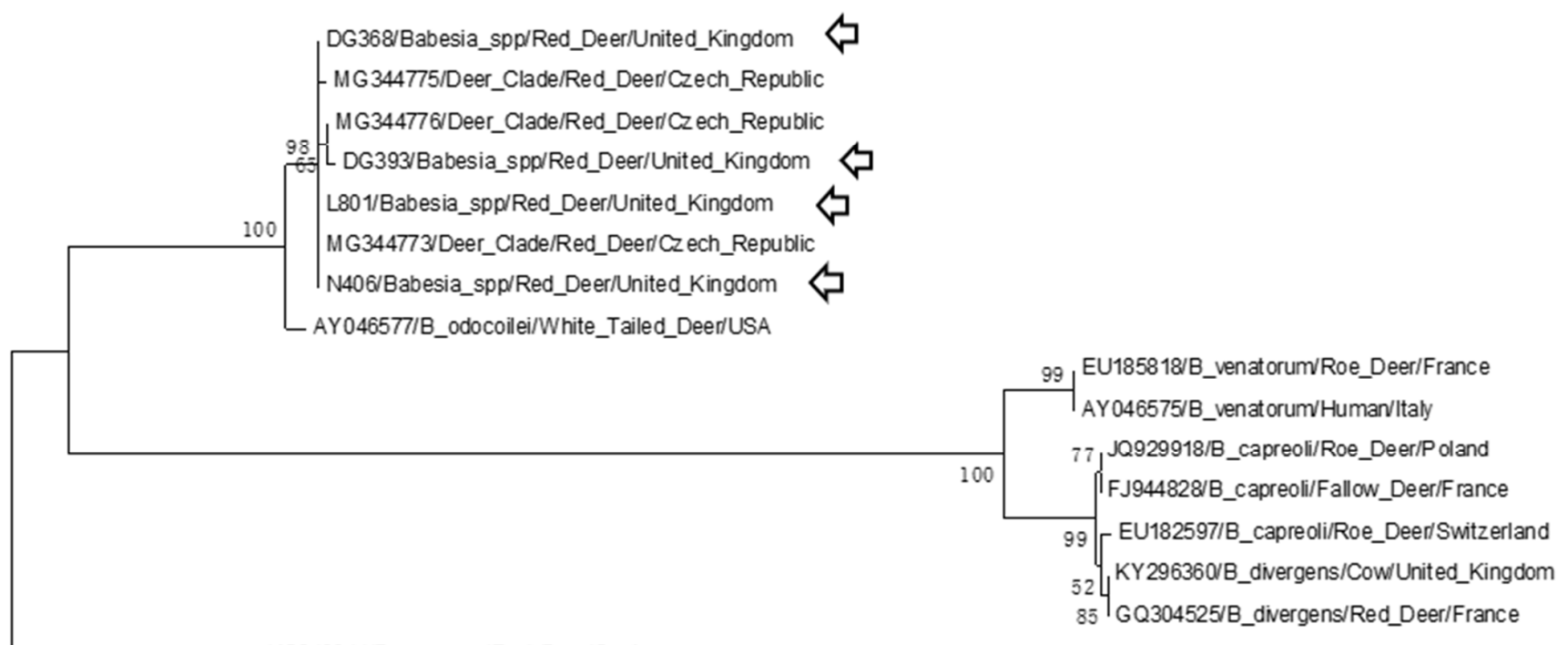

KC249944/B_pecorum/Red_Deer/Spain

0.05

Figure 1. Sequence analysis of UK Babesia sequences with European ruminant-associated 18S rDNA sequences. (A) Alignment of the hypervariable regions of the $18 \mathrm{~S}$ rDNA sequences between position 600 and 655 . The sequences are KY296360 (B. divergens/cow/UK), FJ944828 (B. capreoli, fallow deer, France), EU185818 (B. venatorum/roe deer, France) and MG344775 (deer-clade Babesia, red deer, Czech Republic). The * indicates an insertion/deletion site within the hypervariable region that appears as a single nucleotide deletion within the deer-clade Babesia. (B) Neighbour-joining analysis of deer-associated Babesia spp. A 358 bp fragment of the $18 \mathrm{~S}$ rDNA sequences was used for the analysis with 1000 bootstrap iterations. A Babesia pecorum sequence was used to root the phylogeny. Labels indicated the GenBank Accession number, Babesia spp., vertebrates host and country of origin. Arrows indicate sequences from the United Kingdom. Bootstrap values over 50 are shown.

\section{Discussion}

A total of 105 blood samples obtained from British deer were tested for the presence of three tick-borne pathogens. Although sampled from three geographically separate areas, we detected the presence of a single Babesia species in each herd. Alignment with published Babesia 18S rDNA sequences suggests that this species is a deer-associated Babesia that has variously been termed Odocoilei-like, deer-clade or $\mathrm{CH} 1$. In addition, five animals were shown to be infected with A. phagocytophilum. This pathogen has been reported in Reeve's muntjac in Norfolk in a previous study [38]. In two samples from Norfolk, both pathogens were detected. This survey did not detect the presence of other deer-associated Babesia spp., B. divergens, B. capreoli or B. venatorum. A previous investigation of disease in a herd of reindeer (Rangifer tarandus tarandus) in Scotland reported that seven animals died with clinical signs suggestive of Babesiosis [39]. Intraerythrocytic parasites were observed in blood smears and analysis of the $18 \mathrm{~S}$ rDNA sequence suggested infection with $B$. divergens. 
Subsequent analysis concluded that this was an example of an infection with B. capreoli rather than $B$. divergens [40]. However, this separation is based on a small number of base changes within the $18 \mathrm{~S}$ rDNA sequence, so this observation should be considered tentative. A study surveying red deer in Ireland suggested both B. divergens and B. odocoilei-like species were detected based on the identity of a partial 18S rDNA sequence [41]. The survey reported here suggests that UK deer are also infected, presumably sub-clinically as all the animals were healthy when sampled, with a B. odocoilei-like species. The high $\mathrm{Ct}$ values observed also suggest a low level of parasitemia when compared to cattle with Babesiosis. Alternatively, the extraction of DNA from a haemolysed blood clot may be sub-optimal compared to EDTA-treated blood, giving lower nucleic acid yields.

The absence of WNV antibodies in the deer samples is not surprising as the virus has not been isolated in the United Kingdom and seropositivity in horses is associated with vaccination [42]. Twelve percent of serum samples, mainly from the Scottish county of Dumfries and Galloway, were positive for TBEV. The close antigenic homology between TBEV and the endemic flavivirus Louping ill virus means that cross-reactivity can occur. Serology methods such as ELISA alone are not able to distinguish between the viruses. The infection of Louping ill virus is mainly reported in sheep, although seropositivity has been reported in deer [43]. Tick-borne encephalitis virus has recently been detected in UK deer by serological means and confirmed by the isolation of the virus from I. ricinus ticks from locations that are close to the deer herd sampled from Norfolk [35]. The seropositive results reported here could provide further evidence of TBEV circulation in UK deer, but further surveillance would be needed to confirm this.

\section{Materials and Methods}

Blood samples were taken post-mortem from farmed red deer routinely culled from three locations: the county of Dumfries and Galloway in Scotland; the counties of Norfolk in the East of England and Lancashire in the North of England. The numbers and sex of the deer are shown in Table 1. The samples were allowed to clot and the serum was removed. Residual haemolysed blood around the clot was removed and two hundred microlitres was used from each sample to extract total DNA using the QIAamp DNeasy kit (QIAgen, Manchester, UK) following the manufacturer's protocol.

Each DNA sample was tested for the presence of piroplasms and A. phagocytophilum. A two microlitre aliquot was tested for $A$. phagocytophilum using a real-time PCR that amplifies a $75 \mathrm{bp}$ fragment of the $m s p 2$ gene following the protocol of [44]. Piroplasms were detect in a 5 microlitre aliquot using a pan-piro PCR (primers Piro-A and Piro-B) that amplifies a $400 \mathrm{bp}$ fragment of the $18 \mathrm{~S}$ rRNA gene. The primers and amplification conditions have been published previously [45]. A positive control DNA extracted from the blood of a cow infected with both pathogens was used throughout [46]. The size of the amplicons was confirmed by separation on a $1.5 \%$ agarose gel stained with Sybr ${ }^{\circledR}$ Safe (Thermo Fisher Scientific, Horsham, UK) and visualized with UV illumination. Gel pilot (50 bp) DNA marker (QIAgen) was used to estimate band sizes. The amplicons were sequenced using the Piro-A and Piro-B primers using ABI PRISM ${ }^{\circledR}$ BigDye $^{\circledR}$ Terminator v3.1 Cycle Sequencing Kit (Applied Biosystems, Paisley, UK). Sequences were edited using Lasergene version 12.1 (DNASTAR, Madison, WI, USA). The species of Babesia was confirmed by showing $>99 \%$ identity with publically available sequences (NCBI GenBank database) following a BLAST search. Neighbour-joining analysis was generated using MEGA 5.2 [47] and bootstrap values produced by 1000 pseudoreplicates within the program.

Residual serum samples were tested for antibodies to WNV and TBEV using commercially available enzyme-linked immunosorbent assay (ELISA) kits. These were the ID Screen West Nile Competition Multi-Species (IDvet, Grabels, France) and the Immunozym FSME IgG All Species (PROGEN, Heidelberg, Germany), for WNV and TBEV, respectively. For the TBEV ELISA, samples with a reading of $>126$ Vienna units/mL were considered seropositive. 


\section{Conclusions}

The zoonotic potentials of deer-clade and odocoilei-like Babesia species are uncertain. Cases of human Babesiosis are rare in the UK and associated with infection with $B$. divergens [48]. However, in the original case, species identification relied on the morphology of intraerythrocytic parasites and serology, and was prior to the development of DNA sequencing, the dominant means of assigning Babesia to species. For the other Babesia associated with human infection, $B$. venatorum, no human cases have been detected in the UK $[26,27]$ and cases are rare in Europe [49]. Further studies in all deer species from a wider geographical range are needed to fully understand the Babesia species diversity present within the UK and the role deer play in their maintenance within the tick population.

Author Contributions: Conceptualization, N.J.; investigation, N.J., M.G.; formal analysis, N.J., M.G., L.P.P.; funding acquisition, N.J.; writing—review and editing, N.J., M.G., L.P.P. All authors have read and agreed to the published version of the manuscript.

Funding: This research was funded by the Department for the Environment, Food and Rural Affairs (Defra) and the Scottish and Welsh Governments through grants ED1036 and SE0559.

Institutional Review Board Statement: The samples used for this study were made available to the authors following periodic culling following national guidelines for the management of captive deer. No animals were killed specifically for this study.

Informed Consent Statement: Not Applicable.

Data Availability Statement: Representative sequences from this study have been submitted to the GenBank under the accession numbers MW960417 for sample DG393 and MW969626 for sample DG368.

Conflicts of Interest: The authors declare no conflict of interest.

\section{References}

1. Simpson, V.R. Wild animals as reservoirs of infectious diseases in the UK. Vet. J. 2002, 163, 128-146. [CrossRef]

2. Böhm, M.; White, P.C.L.; Chambers, J.; Smith, L.; Hutchings, M.R. Wild deer as a source of infection for livestock and humans in the UK. Vet. J. 2007, 174, 260-276. [CrossRef] [PubMed]

3. Ward, A.I. Expanding ranges of wild and feral deer in Great Britain. Mamm. Rev. 2005, 35, 165-173. [CrossRef]

4. Schnittger, L.; Rodriguez, A.E.; Florin-Christensen, M.; Morrision, D.A. Babesia: A world emerging. Infect. Genet. Evol. 2012, 12, 1788-1809. [CrossRef] [PubMed]

5. Phipps, L.P.; Hernández-Triana, L.M.; Goharriz, H.; Welchman, D.; Johnson, N. Detection of Theileria luwenshuni in sheep from Great Britain. Parasit. Vectors 2016, 9, 203. [CrossRef] [PubMed]

6. M'Fadyean, J.; Stockman, S. A new species of piroplasm found in the blood of British Cattle. J. Comp. Pathol. 1911, 24, 340-354. [CrossRef]

7. Zintl, A.; Mulcahy, G.; Skerrett, H.E.; Taylor, S.M.; Gray, J.S. Babesia divergens, a bovine blood parasite of veterinary and zoonotic importance. Clin. Microbiol. Rev. 2003, 16, 622-636. [CrossRef] [PubMed]

8. Lewis, D.; Purnell, R.E.; Shaw, S.R. The isolation and characterization of human and bovine strains of Babesia divergens from Drumnadroit, Scotland. Parasitology 1980, 81, 145-155. [CrossRef]

9. Lv, J.; Fernández de Marco, M.; Phipps, L.P.; Macrelli, M.; Otter, A.; Inman, B.; Mitchell, S.; Johnson, N. Molecular detection of Babesia divergens from an outbreak of Babesiosis in Holstein cows, England. J. Vet. Med. Res. 1917, 4, 1078.

10. Brocklesby, D.W.; Zwart, S.; Perié, N.M. Serological evidence for the identification of Babesia major in Britain. Res. Vet. Sci. 1971, 12, 285-287. [CrossRef]

11. Lewis, D.; Holman, M.R.; Purnell, R.E.; Young, E.R.; Herbert, I.C.; Bevan, W.J. Investigations on Babesia motasi isolated from Wales. Res. Vet. Sci. 1981, 31, 239-243. [CrossRef]

12. Woldehiwet, Z. The natural history of Anaplasma phagocytophilum. Vet. Parasitol. 2010, 167, 108-122. [CrossRef]

13. Azagi, T.; Hoogrstra, D.; Kremer, K.; Hovious, J.W.R.; Sprong, H. Evaluation of disease causality of rare Ixodes ricinus-borne infections in Europe. Pathogens 2020, 9, 150. [CrossRef]

14. Alberdi, M.P.; Walker, A.R.; Urquhart, K.A. Field evidence that roe deer (Capreolus capreolus) are a natural host for Ehrlichia phagocytophila. Epidemiol. Infect. 2000, 124, 315-323. [CrossRef]

15. Overzier, E.; Pfister, K.; Herb, I.; Mahling, M.; Böck, G., Jr.; Silaghi, C. Detection of tick-borne pathogens in roe deer (Capreolus capreolus), in questing ticks (Ixodes ricinus), and in tick infesting roe deer in southern Germany. Ticks Tick-Borne Dis. 2013, 4, 320-328. [CrossRef] 
16. Razanske, I.; Rosef, O.; Radzijevskaja, J.; Bratchikov, M.; Griciuviene, L.; Paulauskas, A. Prevalence and co-infection with tick-borne Anaplasma phagocytophilum and Babesia spp. in red deer (Cervus elephus) and roe deer (Capreolus capreolus) in southern Norway. Int. J. Parasitol. Parasites Wildl. 2019, 8, 127-134. [CrossRef]

17. Ebani, V.V.; Rocchigiani, G.; Bertelloni, F.; Nardoni, S.; Leoni, A.; Nicoloso, S.; Mancianti, F. Molecular survey on the presence of zoonotic arthropod-borne pathogens in wild red deer (Cervus elephas). Comp. Immunol. Microbiol. Infect. Dis. 2016, 47, 77-80. [CrossRef] [PubMed]

18. Cézanne, R.; Mrowietz, N.; Eigner, B.; Duscher, G.G.; Glawischnig, W.; Feuhrer, H.-P. Molecular analysis of Anaplasma phagocytophilum and Babesia divergens in red deer (Cervus elephas) in Western Austria. Mol. Cell. Probes 2017, 31, 55-58. [CrossRef] [PubMed]

19. Kauffman, M.; Rehbein, S.; Hamel, D.; Lutz, W.; Heddergott, M.; Pfister, K.; Silhagi, C. Anaplasma phagocytophilum and Babesia spp. in roe deer (Capreolus capreolus), fallow deer (Dama dama) and mouflon (Ovis musimon) in Germany. Mol. Cell. Probes 2017, 31, 46-54. [CrossRef]

20. Latif, B.M.A.; Adam, K.M.G. Antibody to Babesia in Scottish red deer (Cervus elaphus). Nature 1973, 241, 476-477. [CrossRef] [PubMed]

21. Adam, K.M.G.; Blewett, D.A.; Brocklesby, D.W.; Sharman, G.A.W. The isolation and characterization of a Babesia from red deer (Cervus elaphus). Parasitology 1976, 73, 1-11. [CrossRef]

22. Enigk, K.; Freidhoff, K. Babesia capreoli n.sp. beim Reh (Capreolus capreolus). Z. Tropenmed. Parasitol. 1962, 13, 8-20.

23. Duh, D.; Petrovec, M.; Bidovec, A.; Avsic-Zupanc, T. Cervids as Babesiae hosts, Slovenia. Emerg. Infect. Dis. 2003, 11, 1121-1123. [CrossRef] [PubMed]

24. Herwaldt, B.L.; Caccio, S.; Gherlinzoni, F.; Aspock, H.; Slemenda, S.B.; Piccaluga, P.; Martinelli, G.; Edelhofer, R.; Hollenstein, U.; Poletti, G.; et al. Molecular characterization of non-Babesia divergens organism causing zoonotic babesiosis in Europe. Emerg. Infect. Dis. 2003, 9, 942-948. [CrossRef] [PubMed]

25. Bonnet, S.; Jouglin, M.; L’Hostis, M.; Chauvin, A. Babesia sp. EU1 from roe deer and transmission within Ixodes ricinus. Emerg. Infect. Dis. 2007, 13, 1208-1210. [CrossRef]

26. Smith, F.D.; Ellse, L.; Wall, R. Prevalence of Babesia and Anaplasma in ticks infesting dogs in Great Britain. Vet. Parasitol. 2013, 198, 18-23. [CrossRef]

27. Gray, A.; Capewell, P.; Loney, C.; Katzer, F.; Shiels, B.R.; Weir, W. Sheep as host species for zoonotic Babesia venatorum, United Kingdom. Emerg. Infect. Dis. 2019, 25, 2257-2260. [CrossRef]

28. Emerson, H.R.; Wright, W.T. The isolation of a Babesia in white-tailed deer. Wildl. Dis. 1968, 4, 142. [CrossRef]

29. Perry, B.D.; Nichols, D.K.; Cullom, E.S. Babesia odocoilei Emerson and Wright, 1970 in white-tailed deer, Odocoileus virginianus (Zimmerman), in Virginia. J. Wildl. Dis. 1985, 21, 149-152. [CrossRef] [PubMed]

30. Inokuma, H.; Yoshizaki, Y.; Shimada, Y.; Sakata, Y.; Okuda, M.; Onishi, T. Epidemiological survey of Babesia species in Japan performed with specimens from ticks collected from dogs and detection of new Babesia DNA closely related to Babesia odocoilei and Babesia divergens DNA. J. Clin. Microbiol. 2003, 41, 3494-3498. [CrossRef]

31. Hilpertshauser, H.; Deplazes, P.; Schnyder, M.; Gern, L.; Mathis, A. Babesia spp. identified by PCR in ticks collected from domestic and wild domestic and wild ruminants in Switzerland. Appl. Environ. Microbiol. 2006, 72, 6503-6507. [CrossRef]

32. García-Sanmartin, J.; Aurtenetxe, O.; Barral, M.; Marco, I.; Lavin, S.; Lavin, S.; García-Pérez, A.L.; Hurtado, A. Molecular detection and characterization of piroplasms infecting cervids and chamois in Northern Spain. Parasitology 2007, 134, 391-398. [CrossRef]

33. Jouglin, M.; Fernández-de-Mera, I.G.; De al Cotte, N.; Ruis-Fons, F.; Gortázar, C.; Moreau, E.; Bastian, S.; de la Fuente, J.; Malandrin, L. Isolation and characterization of Babesia pecorum sp. nov. from farmed red deer (Cervus elephas). Vet. Res. 2014, 45, 78.

34. Pereira, A.; Parreira, R.; Nunes, M.; Casadinho, A.; Viera, M.L.; Campino, L.; Maia, C. Molecular detection of tick-borne bacteria and protozoa in cervids and wild boar from Portugal. Parasit. Vectors 2016, 9, 251. [CrossRef]

35. Holding, M.; Dowall, S.D.; Medlock, J.M.; Carter, D.P.; Pullan, S.T.; Lewis, J.; Vipond, R.; Rocchi, M.S.; Baylis, M.; Hewson, R. Tick-borne encephalitis virus, United Kingdom. Emerg. Infect. Dis. 2020, 26, 90-96. [CrossRef] [PubMed]

36. Zintl, A.; McGrath, G.; O'Grady, L.; Fanning, J.; Downing, K.; Roche, D.; Casey, M.; Gray, J.S. Changing incidence of bovine Babesiosis in Ireland. Ir. Vet. J. 2014, 67, 19. [CrossRef]

37. Hradilová, K.; Rybářová, M.; Široký, P.; Votýpka, J.; Zintl, A.; Burgess, H.; Steinbauer, V.; Žákočík, V.; Modrý, D. Diversity of Babesia spp. in cervid ungulates based on the $18 \mathrm{~S}$ rDNA and cytochrome c oxidase subunit 1 phylogenies. Infect. Genet. Evol. 2020, 77, 104060. [CrossRef]

38. Duscher, G.G.; Battisti, E.; Hodžić, A.; Wäber, K.; Steinbach, P.; Stubbé, M.; Heddergott, M. First detection and molecular identification of Anaplasma phagocytophilum in an introduced population of Reeve's muntjac (Muntiacus reevesi) in United Kingdom. Mol. Cell. Probes 2020, 52, 101528. [CrossRef]

39. Langton, C.; Gray, J.S.; Water, P.F.; Holman, P.J. Naturally-acquired Babesiosis in a reindeer (Rangifer tarandus tarandus) herd in Great Britain. Parasitol. Res. 2003, 89, 194-198. [CrossRef] [PubMed]

40. Malandrin, L.; Jouglin, M.; Sun, Y.; Brisseau, N.; Chauvin, A. Redescription of Babesia capreoli (Enigk and Freidhoff, 1962) from roe deer (Capreolus capreolus): Isolation, cultivation, host specificity, molecular characterization and differentiation from Babesia divergens. Int. J. Parasitol. 2010, 40, 277-284. [CrossRef] [PubMed]

41. Zintl, A.; Finnerty, E.J.; Murphy, T.M.; de Waal, T.; Gray, J.S. Babesias of red deer (Cervus elaphus) in Ireland. Vet. Res. 2011, $42,7$. [CrossRef] [PubMed] 
42. Folly, A.J.; Waller, E.S.L.; McCracken, F.; McElhinney, L.M.; Roberts, H.; Johnson, N. Equine seroprevalence of West Nile virus antibodies in the UK in 2019. Parasit. Vectors 2020, 13, 596. [CrossRef] [PubMed]

43. Adam, K.M.; Beasley, S.J.; Blewett, D.A. The occurrence of antibody to Babesia and to the virus louping-ill in deer in Scotland. Res. Vet. Sci. 1977, 23, 133-138. [CrossRef]

44. Courtney, J.W.; Kostelnik, L.M.; Zeidner, N.S.; Massung, R.E. Multiplex real-time PCR for detection of Anaplasma phagocytophilum and Borrelia burgdorferi. J. Clin. Microbiol. 2004, 42, 3164-3168. [CrossRef]

45. Fernández de Marco, M.D.M.; Hernández-Triana, L.M.; Phipps, L.P.; Hansford, K.; Mitchell, E.S.; Cull, B.; Swainsbury, C.S.; Fooks, A.R.; Medlock, J.M.; Johnson, N. Emergence of Babesia canis in southern England. Parasit. Vectors 2017, 10, 241. [CrossRef]

46. Johnson, N.; Phipps, L.P.; McFadzean, H.; Barlow, A.M. An outbreak of bovine Babesiosis in February, 2019, triggered by unusual high winter temperatures in southern England and co-infection with Babesia divergens and Anaplasma phagocytophilum. Parasit. Vectors 2020, 13, 305. [CrossRef]

47. Tamura, K.; Peterson, D.; Peterson, N.; Stecher, G.; Nei, M.; Kumar, S. MEGA5: Molecular evolutionary genetics analysis using maximum likliehood, evolutionary, and maximum parsimony methods. Mol. Biol. Evol. 2011, 28, 2731-2739. [CrossRef]

48. Entrican, J.H.; Williams, H.; Cook, I.A.; Lancaster, W.M.; Clark, J.C.; Joyner, L.P.; Lewis, D. Babesiosis in man: A case from Scotland. Br. Med. J. 1979, 2, 474. [CrossRef] [PubMed]

49. Bläckberg, J.; Lazarevic, C.L.; Hunfeld, K.-P.; Persson, K.E.M. Low-virulent Babesia venatorum infection masquerading as hemophagocytic syndrome. Ann. Hematol. 2018, 97, 731-733. [CrossRef] [PubMed] 